\title{
Dissolved: Lessons learned from the Portland Multnomah Food Policy Council
}

\author{
Amy K. Coplen ${ }^{a}$ \\ Portland State University, Toulan School of Urban Studies and Planning \\ Monica Cuneo ${ }^{\text {b* }}$ \\ Portland State University, Institute for Sustainable Solutions
}

\begin{abstract}
Submitted August 7, 2014 / Revised December 2, 2014 / Accepted December 9, 2014 / Published online January 15, 2015

Citation: Coplen, A. K., \& Cuneo, M. (2015). Dissolved: Lessons learned from the Portland Multnomah Food Policy Council. Journal of Agriculture, Food Systems, and Community Development, 5(2), 91-107. http://dx.doi.org/10.5304/jafscd.2015.052.002
\end{abstract}

Copyright (C) 2015 by New Leaf Associates, Inc.

\begin{abstract}
The city of Portland, Oregon, is often hailed in news and popular media as the capital of the U.S. alternative food movement. In 2002, the Portland Multnomah Food Policy Council (PMFPC) was established to address the region's growing interest in cultivating a sustainable local food system. Council members contributed to many notable achievements, including a healthy corner store

a P.O. Box 751; Portland, Oregon 97207 USA; acoplen@pdx.edu

$\mathrm{b} *$ Corresponding author: Monica Cuneo, Mail Code SUST, P.O. Box 751; Portland, Oregon 97207-0751 USA; mcuneo@pdx.edu

Author note

The authors contributed equally to this research and are listed alphabetically. Monica Cuneo was a member of the former Portland Multnomah Food Policy Council from January 2011 to December 2012, served as the vice chair from January 2012 to August 2012 and then as chair from September 2012 to
\end{abstract}

initiative, a beginning farmer training program, and changes to zoning codes to expand urban agriculture. However, the PMFPC was dissolved in the summer of 2012 after local government agencies expressed that the council was losing relevancy. After a decade of conducting food policy and advocacy work in a region praised for fostering both citizen engagement and sustainable food systems, what can we learn from the story of the

December 2012. Her work was made possible by support from Portland State University's Institute for Sustainable Solutions Graduate Research Fellowship. Amy K. Coplen attended meetings of the PMFPC in the summer of 2012, but had no formal affiliation with the council. Her work was supported by National Science Foundation IGERT Grant \#0966376: Sustaining Ecosystem Services to Support Rapidly Urbanizing Areas. Any opinions, findings, conclusions, or recommendations expressed in this material are those of the authors and do not necessarily reflect the views of the National Science Foundation. 
PMFPC? In this reflective case study, we explore the challenges associated with citizen engagement in local food policy. Through semistructured interviews and analysis of PMFPC documents, we provide insight into how particular obstacles might have been avoided or overcome. Our research speaks to the broad arena of public participation and highlights the importance of negotiating and clearly articulating the roles and responsibilities of council members, government staff liaisons, and elected officials; regularly evaluating the usefulness of established roles, structures, and processes; and making the changes necessary to maintain the relevance of the council throughout its life. We conclude with lessons learned and recommendations for both citizens and government agencies hoping to foster productive public engagement and to advance local food systems policy.

\section{Keywords}

food policy councils, food systems, policy, public participation

\section{Introduction}

The city of Portland is often hailed in news and popular media as a capital of the U.S. alternative food movement. ${ }^{1}$ A commitment to local, sustainable, and organic food is embodied in an urban landscape of abundant farmers markets, widespread availability of local and artisanal products, and a vibrant scene of farm-to-table restaurants. The city is home to scores of bountiful community gardens and numerous nonprofit organizations dedicated to promoting urban agriculture, food security, and access to healthy foods. This commitment by farmers, volunteers, entrepreneurs, and foodies to building and sustaining a healthy local food system appears to be matched by a political climate of progressive food and land use policies.

In 2002, the Portland Multnomah Food Policy Council (PMFPC) was established to address the region's growing interest in sustainable food system

\footnotetext{
${ }^{1}$ National news outlets reporting on Portland's sustainable food scene include the New York Times, Los Angeles Times, and National Public Radio (NPR) (Asimov, 2007; Burros, 2006; Norris \& Block, 2009; Robbins, 2005; Timberg, 2008).
}

strategies (City of Portland, 2002; Multnomah County, 2002). The fledgling citizen advisory board was in good company; between them, the city and county host upwards of 70 active citizen boards, commissions, councils, and/or groups that tackle issues ranging from housing and human rights to youth advocacy and agriculture. The PMFPC flourished in this environment so hospitable to citizen engagement. In the last few years of the council's existence, members contributed to many notable achievements, including the creation of the Multnomah Food Action Plan, which laid out a 15year vision and plan for the county's food system; the Healthy Retail Initiative, which provided funding and technical assistance to corner stores interested in increasing healthy options; the Beginning Urban Farmer Apprenticeship Program, which trained new farmers and producers; and updates to the Urban Food Zoning Codes, which relaxed regulations to increase opportunities for urban agriculture.

In light of these successes, many PMFPC members and community supporters were surprised when the city and county dissolved the council in the summer of 2012. While the details of the dissolution were murky at the time, these governing bodies indicated that the PMFPC was losing relevancy and that they had no intention of restructuring or resurrecting a joint food policy council (FPC) in the future. After a decade of conducting food policy and food systems advocacy work in a region praised for high levels of citizen engagement and dedication to building sustainable food systems, what might the dissolution of the PMFPC teach us about the challenges of public participation in local food policy?

Over the past two decades, much-needed research has been conducted on the emergence, development, and structure of FPCs in the United States and Canada. This literature includes important findings related to the specific barriers and challenges these councils face in their efforts to impact food policy. Perhaps unsurprisingly, constraints related to budgets, resources, and time are the most commonly cited hurdles (Borron, 2003; Fitzgerald \& Morgan, 2014; Harper, Shattuck, Holt-Giménez, Alkon, \& Lambrick, 2009; Hatfield, 2012; Scherb, Palmer, Frattaroli, \& Pollack, 2012). 
FPCs often struggle to obtain adequate funding for their work, and because most members are volunteers, coordinating schedules and finding the time to devote to council work can be difficult. These issues can also create hurdles related to the recruitment, engagement, and support of council members (Fitzgerald \& Morgan, 2014; Harper et al., 2009; Hatfield, 2012; Scherb et al., 2012). Productively engaging a diverse constituency is difficult when stakeholders have "differing positions on specific policies and differing abilities to engage in policy" (Scherb et al., 2012, p. 10).

FPCs also face a set of challenges related to navigating complex political climates (Harper et al., 2009). Councils commonly cite a lack of support from government staff as a major barrier to effective and efficient policy change (Borron, 2003; Fitzgerald \& Morgan, 2014; Scherb et al., 2012). Oftentimes councils are faced with trying to coordinate among different government agencies (Hatfield, 2012). Proving the relevancy and usefulness of a FPC can also be difficult, especially when food policy is unfamiliar to government and the public (Borron, 2003). Likewise, members' distrust of government can stand in the way of effective engagement in food policy on the part of government staff and officials (Scherb et al., 2012).

Finally, FPCs often struggle to design and maintain an effective and adaptive organizational structure (Harper et al., 2009). Maintaining strong and consistent leadership while not depending too much on one person is critical to a council's success (Borron, 2003). Harper et al. (2009) cite "balancing focus between policy and program work and between structural and specific foci" (p. 5) as a major challenge experienced by FPCs. Additionally, without systematic evaluation and measurement procedures, it can be difficult if not impossible to adequately evaluate a council's impact (Harper et al., 2009; Hatfield, 2012; Yeatman, 1994).

While this body of literature provides valuable research on the efforts, activities, and struggles of a broad collection of FPCs, it lacks the depth necessary to glean insight from the complex struggles of individual FPCs. A handful of recent individual indepth case studies attempt to fill this gap. These include research on the Oakland Food Policy Council's efforts to influence zoning policy to expand urban agriculture (McClintock, Wooten, \& Brown, 2012); the Toronto Food Policy Council's "nutrition-sensitive food systems approach" (Mah, Baker, Cook, \& Emanuel, 2013); the development of the Food Alliance, a food policy-oriented organization aimed at integrating public health and ecological issues in the Australian state of Victoria (Caraher, Carey, McConell, \& Lawrence, 2013); citizen efforts to formulate food policy to protect farmland in Edmonton, Alberta (Beckie, Hanson, \& Schrader, 2013); the development of "new political spaces" to support urban agriculture in New York City (Cohen \& Reynolds, 2014, p. 221); the Rhode Island Food Policy Council's capacity to model inclusivity and democracy through a food justice orientation (Packer, 2014); and Baltimore's efforts to increase healthy and affordable food access through collaborative food policy (Santo, Yong, \& Palmer, 2014). This body of research seeks to understand the intricacies of particular FPCs while also offering guidance for food systems advocates engaging in public policy.

Our research follows in the footsteps of this important work and provides qualitative evidence that supports many of the challenges identified by the scholars reviewed here. More importantly, we contribute insight into the challenges associated with citizen engagement in local food policy through the lens of the PMFPC. We begin with a brief description of our research methodology. We move on to provide context and background for our research by drawing on literature related to public participation in policy, outlining a short history and typology of FPCs, and detailing the formation and structure of the PMFPC in particular. Next we present the findings from our research on the specific challenges faced by the PMFPC over the course of its lifetime. We conclude with a short summary of these challenges coupled with insight into how particular obstacles might have been avoided or overcome. We present lessons learned and recommendations for both citizens and government agencies hoping to foster productive public engagement and advance local food systems policy.

\section{Applied Research Methods}

We conducted semistructured interviews with 10 
key informants identified using a purposive sampling frame. We chose interviewees who represented the diversity of stakeholder roles on the PMFPC, including four former members and chairs, two city and one county staff liaison, an expert in public policy, and two longtime supporters who attended PMFPC meetings regularly. We recruited interviewees who were present during various stages of the lifetime of the PMFPC, including its formative years, its dissolution, and stages in between. To maintain confidentiality we refrain from using names, but we identify council affiliation to provide context for interview excerpts.

We analyzed interview transcripts, PMFPC documents, and monthly meeting minutes using the Dedoose qualitative coding application. It is important to note that one of the authors was a member of the PMFPC and served as council chair during the time of dissolution. ${ }^{2}$ The other author was new to Portland in 2012 and attended meetings of the PMFPC in the summer of 2012, but had no formal affiliation with the council. We recognize that our positionality has influenced all stages of this project, including the research design, data collection, and data analysis, as is the case with all research (Burawoy, 1998). We attempted to balance our "insider"/"outsider" perspectives by working together throughout each stage of the research process, including co-developing interview guides, cross-coding interview data, and seeking input from and fact-checking by individuals with various affiliations and relationships with the PMFPC over its lifetime.

\section{Background}

\section{Public Participation}

Public participation in policy-making takes many shapes and serves a variety of functions. Opportunities include public hearings, citizen forums, community meetings, outreach, citizen advisory

\footnotetext{
${ }^{2}$ Monica Cuneo was a member of the PMFPC from January 2011 to December 2012, and served as the vice chair from January 2012 to August 2012 and then as chair from September 2012 to December 2012.
}

boards, individual citizen representation, citizen surveys, and focus groups (Wang, 2001). Motivations for participation in policy-making are also numerous and include a desire to be engaged in the public sphere, to hold a more active role in decision-making, and to act as a government watchdog (Irvin \& Stansbury, 2004; Wang, 2001). Public participation has the potential to enhance two-way communication and education between governments and the citizens they serve. In particular, it can provide policy-makers with insight into issues of public concern. Likewise, it can increase public awareness of policy-makers' jurisdictional limitations. Policy-makers can use public participation as a vehicle for managing the public's expectations and educating citizens in regard to identifying efforts that have the most potential to affect policy, while providing a platform and structure for obtaining public input (Irvin \& Stansbury, 2004; Wang, 2001).

Public-participation processes ideally employ strategies to maximize citizen engagement and a sense of ownership among participants. These strategies, however, have varying degrees of efficacy and differ in regard to the level of decisionmaking power they grant to citizens. Scholars of public participation have worked to classify degrees of citizen power in decision-making. Sanoff (2000) distinguishes between "pseudo" and "genuine" engagement, where the former might consist of policy-makers simply informing citizens of existing processes used in decision-making, while the latter describes arrangements by which citizens are granted jurisdiction, authority, and control over decisions. "Genuine" engagement involves citizens working in partnership with policy-makers to serve as owners and "co-producers" of public policy (Sanoff, 2000; Wang, 2001).

Arnstein's (1969) ladder of citizen participation is also useful for conceptualizing varying degrees of citizen power in decision-making. At the lower rungs of her virtual ladder are "manipulation" and "therapy" - stages of nonparticipation. Continuing upward on the ladder, "informing," "consultation," and "placation" indicate stages of the tokenization of participants or the process or both. Moving further up the ladder toward "partnership," "delegated power," and "citizen control," 
the integration of citizen input and shared power in decision-making increases.

Municipal governments often have trouble seeking input from broad, diverse segments of the population. This gap in participation allows a narrow group of individuals to dominate the public participation process and limits access by traditionally underrepresented communities. A lack of participation can be interpreted by government bodies as apathy or lack of interest (Irvin \& Stansbury, 2004; Yang \& Callahan, 2005). However, citizens often consider the process of creating policy to be overly academic and removed from community experiences (Schiff, 2008). Formal group and meeting structures may be unfamiliar and intimidating to community members, thereby inhibiting active participation from a diverse citizenry (Duran, Wallerstein, Avila, Belone, Minkler, \& Foley, 2012). While specific expertise may be needed in areas such as budgeting, personnel, and procurement policies, when citizens and government staff operate with narrow definitions of expertise, they limit participation and fail to consider community knowledge as being "equally legitimate" (Duran et al., 2012, p. 52). A broader definition of expertise encourages public engagement from a larger segment of the population (Wang, 2001).

\section{Food Policy Councils}

Food policy councils (FPCs) began to emerge in the 1980s as cross-sectoral groups focused on engaging a broad range of stakeholders to develop sustainable local food systems (Schiff, 2008, p. 206). In the mid-1990s, the Local Food Systems Project, a three-year project funded by the W. K. Kellogg Foundation and managed by the Minnesota Food Association, provided technical assistance to develop FPCs in six U.S. cities and documented this work to guide future food policy efforts (Dahlberg, Clancy, Wilson, \& Donnell, 1997). As of September 2014, there were 200 FPCs nationwide, existing in a variety of forms and with a range of functions (Center for a Livable Future, 2014). FPCs typically fall into three main categories. Governmental FPCs, like the former Portland Multnomah Food Policy Council (PMFPC), advise government agencies as commissions, task forces, or advisory boards; utilize government staff support; and have limited decision-making power (Fox, 2010; Scott, Scott, Oppenheimer, Walton, \& Gahn, 2011). Nonprofit and independent FPCs operate autonomously, without formal government affiliation (Dahlberg, 1994; Schiff, 2008). Finally, quasigovernmental and hybrid FPCs may be affiliated with government agencies, but like independent councils, maintain full decision-making power within the organization (DiLisio, 2011; Schiff, 2008).

The objectives of FPCs vary based on the perceived needs and concerns of the community, the backgrounds and interests of council members, the funding opportunities available, and the current political climate (Burgan \& Winne, 2012; Dahlberg, 1994). However, some common objectives include developing programs to address community needs; advocating for particular food policies; educating the public; convening disparate stakeholders; and strategizing for more sustainable food systems (DiLisio, 2011; Schiff, 2008; Scott et al., 2011). Notably, research suggests that interest in policy versus projects versus programs often shifts over time; groups that start with a projects or programs focus sometimes shift to a policy orientation and vice versa (Schiff, 2008). However, as we will demonstrate, the lines between policy, projects, and programs are not well-defined or commonly shared. Goals, objectives, and roles and responsibilities are also terrains of debate and misunderstanding. Therefore, it is important to agree upon a shared vision, to define the council's role and purpose during its formative stages, and to revisit these periodically to ensure that the group remains effective (Fox, 2010).

\section{Formation of the PMFPC}

In February 2002 a group of concerned citizens, farmers, and organizational representatives working on issues related to food security, food production, community gardening, hunger, and nutrition held a community food forum that gathered over 100 food systems stakeholders. The forum signaled the increasing political relevance of food, demonstrated the momentum of citizens organized around food issues regionally, and helped to place food systems issues on the radar of government 
officials. Over the course of several hours, participants identified six main food system problems that they saw as important to tackle from a policy angle:

- food practices in medical and government institutions that promote unhealthy diets and poor environmental stewardship;

- a lack of awareness by local residents regarding nutrition, food skills and the source of their food;

- a high rate of hunger and barriers preventing access to affordable, nutritious food for local residents, regardless of income level or geographic location;

- urban land use policies and rules negatively affecting local food production and distribution;

- business and economic issues affecting the viability of local farmers; and

- the environmental impacts associated with food production, consumption, and waste disposal (City of Portland, 2002, p. 1; Multnomah County, 2002, p. 1).

Forum organizers sought to establish a formal relationship with government and targeted City Commissioner Dan Saltzman, who attended the forum at their request, as a political champion who would bring food policy issues to the agenda of the city council. City and county government officials also began to recognize the advantages of a formalized, food-focused citizen advisory board: it would be an opportunity to establish a commitment to food systems and to identify food-related problems and potential policy interventions. One former government staff liaison to the PMFPC reflected,

[The PMFPC] was viewed as the logical first step for the city and county to try to take input on food issues, because none of us had staff or programmatic attention at that point...so it provided a formal place for that discussion to play out and, you know, it led to the City dedicating resources to creating a food program.

Commissioner Saltzman ushered in the May
2002 city resolution, followed by a corresponding county resolution in June, which established the PMFPC as a joint citizen advisory board between the city and the county (City of Portland, 2002; Multnomah County, 2013). ${ }^{3}$ The PMFPC was housed as a subcommittee under the Sustainable Development Commission, which also served as a joint advisory board. As a citizen advisory board, the PMFPC had no official decision-making power, and policy-makers were not bound to its recommendations. Rather, the founding resolutions stated that the PMFPC's initial charges were to provide ongoing advice to the city and county on food policy issues; to establish governing principles to guide decision-making related to food issues; to identify and report to the city and the county on options for improving local policies, rules, and practices related to food production, availability, and demand; and to develop a work plan, proposed structure, and potential funding opportunities (City of Portland, 2002; Multnomah County, 2002).

The first 11 members of the PMFPC were selected by the city and county and were what one former council chair referred to as the "cream of the crop": restaurant and grocery store owners, university faculty and staff, health-care researchers and providers, a former farmer, and other seasoned practitioners in the field of food systems, hunger, and nutrition. The founding resolutions defined the make-up of council members and participants as "representing the diversity of the local community and providing a wide range of expertise on local food issues including hunger relief; nutrition; food business and industrial practices; local farming; community education[;] and institutional food purchasing and practices" (City of Portland, 2002, p. 2; Multnomah County, 2002, p. 2). Following the

\footnotetext{
${ }^{3}$ The relationship between the city of Portland and Multnomah County governments is dynamic, overlapping, and not clearly documented. The city generally manages water, sewer, solid waste, and parks. The county manages libraries, health and human services, and judicial systems. Both governments manage transportation infrastructure, education, public safety, and housing (Griffin-Valade, Kahn, \& Gavette, 2013). Joint advisory boards, like the PMFPC, are sometimes formed when both governments identify a need or stake in a particular issue.
} 
initial membership selection, the mayor of Portland and the Multnomah county commissioner implemented a formal application process to appoint new members. This consisted of prospective members submitting a statement of interest and responses to a series of questions related to the applicant's experience with food and policy. Recruitment and review of applications occurred annually for any open seats on the PMFPC, and members served two-year terms for a maximum of two terms. While council members engaged in recruitment activities, they did not initially advise on or take part in the selection process, and the selection criteria used by the city and county were not public. In the last two years of the PMFPC's lifetime, efforts were made to make the process more transparent, including the formation of a committee dedicated to recruitment and selection. ${ }^{4}$

In addition to the appointed council members, the PMFPC was staffed with liaisons from both the city and county. Their role was to attend PMFPC meetings; to coordinate meeting logistics such as space use, minutes, and agenda; to serve as liaisons between the PMFPC and elected officials; to advocate for the PMFPC and its recommendations; to advise the PMFPC on city and county priorities; and to assist the PMFPC with the creation of work plans based on city and county goals (City of Portland \& Multnomah County, 2012). However, perceptions about the degree to which staff should support the PMFPC and what form that support should take, the extent to which they should control agenda setting, and their specific role and function as liaisons to elected officials varied significantly among our interviewees, an issue we discuss in further detail below.

\section{Research Findings}

"Welcome to the Big Leagues": The PMFPC's Lack of Autonomy, Authority, and Influence

Former PMFPC members we interviewed generally conceived of an ideal food policy council as a body working in partnership with government and

\footnotetext{
4 This new selection process was used only once before the Council was dissolved the following year.
}

having some level of autonomy and authority to influence policy. However, they expressed frustration with regard to the PMFPC's overall lack of influence and felt that the government failed to foster good communication and "genuine" citizen engagement in the policy process. Placing the PMFPC on the "pseudo" end of Sanoff's engagement spectrum (2000) and on the "informing" rung of Arnstein's ladder of participation (1969), one former government employee and active supporter of the PMFPC noted that "the county and the city would report on what they were doing" by "dumping" information rather than engaging in "a two-way relationship" or "an exploration going both ways." According to another interviewee and former member, "there was very little effort to kind of empower [the PMFPC] to do useful work and to give them some autonomy and authority to do that work." Another former member shared the perception that it is the responsibility of government liaisons to empower citizens and yield them autonomy and authority: "the food policy council is about the public — the public's will and role with respect to creating a food system that works. And unless you can power that role, then you're not doing the work of a food policy council." One former staff liaison indicated that the council members themselves were ultimately in control of the level of power and influence they yielded, noting that "depending on how effective [they are] at the work that they do and making their voice heard, I think that any council...can be as effective and as present and vocal and as high profile as [they] want to be."

Both former PMFPC members and government staff we interviewed agreed that the ideal role of a staff liaison was to navigate the council through the policy process. But there was some disagreement about who should be driving the agenda. Former staff liaisons considered the two main roles of the council to be (1) advising on issues that government had identified as high priority, and (2) calling attention to important issues that are not currently on the radar of elected officials. However, former liaisons expressed frustration about what they viewed as council members' lack of interest in the projects that elected officials were actively engaged in. "We 
would say, "here are the issues that we are working on, it would be really great to have help with this, because this is what will be of highest profile among the elected," recounted one former staff liaison, "but there wasn't anyone that wanted to follow, you know, who wanted to work on those particular issues."

One former PMFPC member had quite a different vision of the role of a staff liaison: "the job of a staff person is to mostly listen-figure out what it is [council members] want to see happen and why they want to see it happen and to facilitate that happening." Another former member expected government liaisons to provide "guidance and direction" and to facilitate a process whereby members could identify food system issues ripe for tackling from a policy angle. This ideal vision conflicted with how former members experienced government support on the ground.

Several former PMFPC members recounted experiencing staff liaisons as "gatekeepers" who controlled access to the political process and sought to impose their own agenda on the PMFPC. For one former member, "gatekeeping" included staff refusing to publish food system reports and research that the PMFPC had produced, blocking communication with policymakers perceived to be "higher up," and limiting access to materials that would facilitate group process. Another former member noted that although "the initial FPC did awesome at getting the issues on the radar of the elected officials," in later stages "it seemed that most staff people were handlers and gatekeepers - preventing people from having interesting conversations." This interviewee continued,

Having [government liaisons] sort of driving the agenda towards their specific projects or what they needed to have happen really kind of kept the playing field kind of small and prevented citizens from having direct access to elected officials to really tell them what they were thinking. And to me it seems like a citizen advisory group really should have its own agenda and its own mission, and its goal is to provide input into elected officials and staffers. And based on having the handlers in the middle it sort of watered down the message and made it so we couldn't be honest. I couldn't be honest about the situation because the handlers were there and I didn't want to basically affect their jobs.

For many former members, their experience with "gatekeepers" was disempowering and was considered a primary reason for lack of traction and progress made toward advancing food policy. When asked to explain why policy-makers sometimes did not respond to the recommendations of an advisory board, a public-policy expert we interviewed replied bluntly, "welcome to the big leagues." A former government employee and selfidentified longtime PMFPC advocate expanded on this, suggesting that advisory groups' policy objectives do not always align with those of government officials:

Don't forget, elected officials like to have the appearance of high capacity advisory groups or policy influencing groups and ultimately know that they are going to make their own decisions and it's predicated not on those same factors that that policy group necessarily is using to make their recommendations. And that's just the nature of the political process.

As a citizen advisory board, the PMFPC did not have the authority to make policy decisions. Yet council members expected that staff and elected officials would hold their advice and recommendations in high regard. They were frustrated by what they perceived as a failure on the part of government to facilitate two-way communication and productive public engagement in the policy process. Former members felt that the PMFPC was met with a lack of government support, which Borron (2003), Fitzgerald and Morgan (2014), and Scherb et al. (2012) identify as one of the main challenges facing FPCs. Former staff liaisons, on the other hand, felt as though the PMFPC was not interested in supporting or advising on the issues that were of top priority to elected officials. Rather than serving as "co- 
producers" of policy, sharing power, and achieving a public partnership, former members and staff liaisons were operating with disparate agendas and were ultimately unable to have the type of meaningful policy impact they had hoped for.

\section{"A Slow, Painful Death by Bureaucracy": The Absence of Strategic Planning, Communication Breakdown, and Fractionalization}

According to Harper et al. (2009), FPCs require well designed organizational structures, strategic planning, and evaluation processes to remain productive and sustainable over time. The PMFPC lacked a formalized strategic planning schedule, which contributed to its inability to participate in and develop both long- and short-term advocacy strategies. The 2002 founding resolutions were never revised to reflect changes to the council's structure or function. For example, the Sustainable Development Commission (the joint city-county advisory board under which the PMFPC was a subcommittee) was dissolved in 2007, and although the PMFPC then began operating independently, the original resolutions were never updated to reflect this. Many of the council's tasks, responsibilities, and regularly scheduled activities had evolved or dropped off altogether, having since been completed or considered no longer relevant to the group. These changes were never documented, which made evaluating the council's impact difficult, if not impossible.

Former members cited the importance of communicating directly with city and county commissioners on a regular basis; it was an opportunity for the PMFPC to make recommendations in its own words and to communicate progress, goals, and research findings. However, over the years, members received less and less face time with elected officials, instead communicating almost exclusively through government staff liaisons. One former staff liaison attributed this to a "radical change" in the composition of the PMFPC and the composition of the food policy landscape over time. A founder and former chair described the consequences of this growing disconnect on the efficacy of the council: "I think gradually the Council started to lose its teeth, its momentum, and its profile in front of those commissioners."
According to one former chair, without a direct link to elected officials, the PMFPC "got stuck in the administrative process" and began "a slow painful death by bureaucracy." The loss of direct communication between the PMFPC and elected officials also made it difficult for the council to productively navigate complex relationships with two government bodies, each of which had separate jurisdictional responsibilities and oftentimes disparate goals related to food policy. Consistent with Harper et al.'s research, which identifies "working in complex political climates" as one of the six main challenge facing FPCs (2009, p. 5), former council members emphasized that growing conflict between city and county staff was negatively affecting the efficacy of the PMFPC. As one citizen at large and longtime advocate of the PMFPC reflected,

What I gathered was happening was increasing lack of cooperation between the city and county. Whether that was personality driven, or policy driven, or driven by any other number of factors, it didn't matter to me, and I never weighed into that nor did I ever want to (chuckle), but it was just clear that there was a fractionalization that was going on that kept the food policy council from operating at an optimal level.

The absence of a strategic planning process, the breakdown of communication between the PMFPC and elected officials, and the growing tension between the jurisdictions jointly housing the PMFPC contributed to ongoing confusion about the overall role and function of the council and the roles of individual council members and government staff liaisons. Without supportive structures, formal organizing documents, written agreements, and robust communication pathways, the group was unable to develop and maintain a shared vision and strategic direction.

\section{Training and Capacity-Building}

Research suggests that a comprehensive understanding of the policy process is critical to building citizens' capacity to participate in policy creation (Irvin \& Stansbury, 2004; Wang, 2001) and that 
training and skill-building in this arena is one of the biggest challenges facing FPCs (Scherb et al., 2012). Many of our interviewees agreed that members should at least have rudimentary policy literacy, including knowledge of existing policies related to food systems, an understanding of the process of policy development, and a sense of the role of advocacy in policy creation. However, they expressed different perceptions about how and when this knowledge should be attained and who was responsible for providing the necessary training. Some interviewees identified the need for all members to have strong comprehension of the policy process upon appointment to the PMFPC, while others felt that a few experienced participants could provide the leadership and institutional memory necessary to guide the rest of the group.

One former council member noted that local governance systems are complex and difficult to navigate, and that it is the responsibility of government staff to educate participants on how to influence policy in a "solutions-based way." One former staff liaison we interviewed recalled facilitating orientations at the beginning of each year and bringing in outside policy experts to educate members on "policy 101," but that in the last couple of years of the council's existence, former council chairs "wanted to take over that function." Council documentation dated 2006 lists "work [ing] with staff and FPC members to orient new council members and encourage their participation on committees" as the responsibility of the council chair, although interviewees did not reference this document nor did they point to this as a task assigned to the chair specifically (PMFPC, 2006). One former staff liaison we interviewed indicated that although it was preferable to have members on the council who were up to speed on policy, it was ultimately the responsibility of government staff to help the council navigate the process. One interviewee who as a government employee had supported the formation of the council argued that it was the responsibility of members to educate themselves and "build capacity" to advocate on relevant issues:

I don't think the city and county has [sic] the responsibility of building capacity...the capacity gets built within the members of the organizations themselves and filling a vacuum where one exists, creating opportunities where they can. All that is driven, not by the county saying, "y'all come, tell us what we should be doing," but by the members saying, "this is what you should be doing on this issue."

While there was disagreement on who was responsible, nearly all interviewees agreed that there was an overall dearth of literacy and navigability of the policy process, which contributed to members feeling powerless, ineffective, and ill equipped to engage meaningfully. Similar to the findings of Scherb et al. who cite "differing abilities to engage in policy" as a challenge to successful food policy creation (2012, p. 10), one former staff liaison stressed the importance of developing a common understanding of the policy process in order to create a "level playing field" so that the advice of council members who were well versed in the policy process was not privileged over that of those who were less experienced. "Staff need to create opportunities to learn from advisory boards, not just target the smartest person in the room and talk to them exclusively about a specific issue," noted the former member, continuing, "if the goal is public policy, then expertise needs to be shared."

\section{"The Cream of the Crop": Defining Expertise and Inclusivity}

The first cohort of the PMFPC was considered "the cream of the crop," representing "people with knowledge of some aspect of the food system based on longtime experience," according to a founding member of the council. This included influential restaurant and grocery store owners, university professors, and the executive director of an area food bank. Interviewees noted that while the council may have had wide representation from different sectors of the food system, it was lacking in racial and cultural diversity, which reflects one of the six main challenges facing FPCs as identified by Harper et al. (2009). Some pointed to the fact that regular attendance at monthly council meetings was prohibitive for many members of the community, particularly those who were not able to take time 
off from work, had difficulty arranging transportation, and/or had limited English proficiency.

Some interviewees made a distinction between "experts," or those professionally affiliated with a sector of the food system, and those with "life experience," typically defined as someone who faced food insecurity or other food-related issues in their personal lives. Although most interviewees expressed that both perspectives were valuable from the standpoint of food policy, there were differing opinions about how to best incorporate the knowledge of underserved populations into the PMFPC's work. One former member considered it sufficient to have members on the council who worked directly with food-insecure populations and to conduct outreach to communities unable to attend meetings. Another interviewee, who served as a council chair, recounted frustration in trying to persuade government staff that the council needed direct representation from food-insecure populations, and chalked it up to a lack of cultural competency on the part of unconvinced staff. This same interviewee recalled debates about how to achieve more inclusive participation:

Having equitable representation...takes some real thought and it's probably going to have to be an alternative type of advisory group, meeting at different times, or even talking about meeting in different languages or different places, you know, like the city of Portland go[ing] all the way out to East Portland, and we could not get anybody to agree to meet out there from the staff members because they thought it was too far. And that's really irresponsible, I believe. If you're talking about a community advisory committee and you don't want to meet outside downtown that's not being equitable or inclusive.

A staff liaison we interviewed also expressed concern with regards to inclusivity, noting that in order to "branch out" and bring in new people, the group "need[ed] to be able to function differently so that people [felt] comfortable and welcomed and part of the group." The same interviewee mentioned that council members had expressed commitment to cultivating and mentoring new members, but had failed to follow through. These problems are not unique to the PMFPC. Other FPCs have also experienced difficulty recruiting, engaging, and supporting new members (Fitzgerald \& Morgan, 2014), in part because citizens sometimes consider policy to be overly academic, unfamiliar, and inaccessible (Duran et al., 2012; Schiff, 2008).

Our interviewees noted that the composition of the PMFPC changed significantly over time. One former staff liaison mentioned that as the council matured, numerous other food systemsrelated organizations came on the scene. The presence of these new organizations reflected a growing local food movement, but also diluted the influence and necessity of the council in the policy arena. This made it difficult to continue to recruit seasoned and influential members, such as the executive directors of prominent nonprofits. A former member and chair argued, "the most politically savvy foodies [were] being chewed up and spit out and [were] not willing to return, so the remaining set of available persons were those that didn't have the policy expertise." Indeed, as interest in local food systems grew, the council gained a higher public profile and began to attract community members who were passionate about food issues but were not necessarily policy experts. As fewer "high powered" people participated, the council continued to lose political power. Former council members suggested that these changes to membership composition and the higher degree of mediation on the part of staff liaisons contributed to the decline of outreach to elected officials and ultimately to its dwindling relevancy in their eyes.

\section{Policy Versus Projects Versus Programs}

As PMFPC members grasped for opportunities to understand the overall policy process and how they could best address the food system issues affecting the communities they were working with, the lines between projects, policies, and programs became blurred. As one former staff liaison reflected, "I had always understood the reason it was called the food policy council was that it would focus on policy not projects, and I understood the council to be essentially providing guidance to the city and 
county to get our houses aligned with the policy goals." However, when asked to expand on the relationship between policy and projects, the staff member acknowledged that it was not a "black and white situation." Rather, the PMFPC engaged in activities, such as food-focused workshops, listening sessions, and neighborhood-specific meetings, as a way to understand issues at the community level and to help inform needs and opportunities that could lead to policy issues being "flagged" for future redress.

Another former staff liaison expressed frustration with what they perceived as a lack of clarity about what would be the specific policy recommendations that would emerge from project-based work. The same former liaison indicated that the slipperiness between policy, projects, and programs is not unique to the former PMFPC, but is "always a big topic of discussion" at conferences where attendees often ask, "are we doing policy or are we doing programs?" According to Scherb et al. (2012), this confusion is indicative of broad lack of consensus over the term "policy." Hatfield (2012) emphasizes the importance of distinguishing between policy work and project work, defining the former as "identify[ing] and engag[ing] with those areas in which local government touches or shapes the city food system," and the latter as "involv[ing] the development and implementation of specific initiatives" (p. 19). Interestingly, work by Schiff (2008) suggests that interest in policy versus projects versus programs often shifts over time, and groups who may start with a project or program focus sometimes shift to a policy orientation or vice versa.

Indeed, confusion about the role of the PMFPC in regard to its involvement in policymaking, projects, and programs was more than an issue of semantics. According to interviewees, the lack of shared understanding about the distinction between these categories and the type of work that was appropriate for the council to engage in contributed to disagreement about the roles and responsibilities of staff and council members alike. Ultimately, this hindered the council from effectively engaging in meaningful food policy.
Dissolved: The Technical Nail in the PMFPC Coffin In June 2012, the chair and co-chair of the PMFPC resigned, citing frustration with the pace of change in the "government policy arena" (D. McIntyre, personal communication, June 23, 2012). Government liaisons stressed that the council was becoming increasingly ineffective as an advisory body and was losing relevance to both policy-makers and council members (PMFPC, 2012a). Meeting minutes and interview transcripts reveal a number of reasons for the perceived waning relevancy of the council, which Borron (2003) identifies as one of the most pressing challenges facing FPCs. The city of Portland noted that the council was "operating in a different food environment" than when it had been conceived a decade ago (PMFPC, 2012a, para. 6). Many new food-related organizations had sprung up and some previously existing organizations had shifted or expanded their focus to include food. Elected officials had begun to look beyond the PMFPC to seek niche expertise based on particular policy goals, and the city and the county, in large part due to the advice of the PMFPC, had institutionalized food-related work in the form of full-time staff positions. Council members agreed that the food landscape had changed and that the council should be restructured to reflect these changes (PMFPC, 2012a).

It was also clear that PMFPC members and staff liaisons had different food policy agendas, making collaboration difficult. Government liaisons expressed that the council was working on important issues, but that their work was not directly filling the needs of the city and county (PMFPC, 2012a). They further expressed the desire to "pause" for reflection, to lay out a clear path forward, and to engage in strategic planning before electing new leadership. The council appointed an interim chair and formed a work group charged with revisiting the original city and county founding resolutions, leading a restructuring process, and redefining the council's role and function (PMFPC, 2012a, 2012b).

But the effort came too late. In September County Chair Jeff Cogen reported that the 2007 dissolution of the Sustainable Development Commission, under which the PMFPC was legally housed, had "unintentionally dissolved the FPC" 
(PMFPC, 2012a, para. 2). Cogen further communicated that, due to a "basic division of responsibilities between the city and county," both jurisdictions had agreed that they would not continue to be involved in a "joint effort" (PMFPC, 2012a, para. 2). The council and Commissioner Cogen negotiated a three-month period to reflect on the desired roles of each party moving forward. However, the majority of council members considered Cogen's announcement to be a technical dissolution of the council. The PMFPC continued to meet through December to discuss next steps. Discussions revolved around reinventing the council and determining what shape the next iteration should take.

\section{Update on the State of Food Policy in the} City of Portland and Multnomah County

Ultimately, the group decided to pursue a new model that would operate independent of local government bodies. In the summer of 2013, a handful of former PMFPC members as well as other interested individuals from the region formed the Portland Area Food Forum (PAFF) - "a citizen led collaborative striving to establish a cohesive network among food justice and food systems work in our region, create space for interaction, and generate effective practices for establishing a just food system" (PAFF, n.d., para. 1). The PAFF convenes quarterly networking socials as well as forums focused on topics such as food access and racial and class equity. PAFF embodies participants' desire to focus on food justice and advocacy, convene a diverse network of individuals and organizations engaged in food systems change, and support more action-oriented projects. The emergence of the PAFF signaled participants' desire to move away from a strict policy orientation to more project-based work, a shift that Schiff (2008) identifies as commonly experienced by FPCs.

In April 2013, Multnomah County developed a new Food Advisory Board (FAB) to "provide specific recommendations to Office of Sustainability staff on ways county services, departments, and offices can leverage the local food system in order to improve the health, safety, equity, and prosperity of the community... [and] the delivery of public services” (Multnomah County, 2014). To the authors' knowledge, the county FAB is no longer meeting regularly. The city of Portland has not articulated intent to form another standing advisory board related to food policy, but instead plans to continue with time- and content-specific ad hoc committees.

\section{Conclusion: Lessons Learned}

Through the Lens of the PMFPC: The Challenges of Public Participation

Former members of the PMFPC communicated the potential for the PMFPC to serve as a vehicle of "genuine" engagement, whereby they would be "co-producers" of public policy (Sanoff, 2000; Wang, 2001). However, they described their experience as one more consistent with "pseudo" engagement. They felt that government staff failed to foster two-way communication and ignored recommendations and reports produced by the council. Former members were frustrated by their lack of authority and decision-making power, yet this is the nature of a citizen advisory board as defined by the city of Portland and Multnomah County. A former government employee and selfidentified long-time PMFPC advocate argued that elected officials sometimes based their decisions on a different set of factors than the council was using to make its recommendations and that this was "just the nature of the political process."

Former PMFPC members wanted staff liaisons to help navigate the policy process, but instead identified them as "gatekeepers" who prevented the council from accessing elected officials. Former staff liaisons felt that council members were not interested in working on the issues that were of top priority to elected officials and would therefore have the most meaningful impact. Former council members' perception of a growing tension between the city and county made it difficult for the council to negotiate between the two governing bodies' goals and needs. Rather than serving as "coproducers" of policy, sharing power, and achieving a public partnership, former members and staff liaisons were operating with disparate agendas and were ultimately unable to have the type of meaningful policy impact for which they had hoped.

Differing perceptions of the roles and 
responsibilities of the council, its individual members, and the government staff assigned to support them was a common theme throughout the interviews. There was no consensus on who was responsible for providing the policy literacy training and capacity-building necessary to effectively identify opportunities for policy intervention and to go about spearheading policy change. As council members found themselves drawn to more actionoriented "projects," staff became frustrated at the lack of attention paid to "policy" outcomes. Overall, there was not a shared understanding about the type of work that was appropriate for the council to engage in, or the roles and responsibilities of both parties in moving the work forward. The absence of a strategic planning process also contributed significantly to the inefficacy of the PMFPC, particularly toward the end of its life. The council's structure, function, and mission were not consistently revisited or revised, leaving governing documentation outdated and, in some cases, irrelevant - the most egregious example being that on paper the council had technically been defunct for five years.

There was also disagreement about how "expertise" should be defined in regard to the recruitment and appointment of council members. A few former members expressed frustration with the lack of racial and cultural diversity on the council. One member recounted being met with resistance when they advocated for granting membership to people who may not have professional ties to food systems, but experienced food insecurity in their personal lives. One former staff liaison expressed that council members had committed to recruiting new and more diverse members, but had failed to follow through. Had there been formal discussion and negotiation about how to define expertise and how to recruit new members, perhaps both parties could have found a middle ground.

\section{Recommendations and Final Thoughts}

After a decade of conducting food policy and food systems advocacy work in a region praised for high levels of citizen engagement and dedication to building sustainable food systems, the story of the PMFPC has much to teach us about the challenges of public participation in food policy. We have explored the struggles faced by the PMFPC over the course of its lifetime, and have identified key factors that contributed to the decline of its efficacy and its perceived irrelevance in the eyes of elected officials and council members alike. We offer the following recommendations for fostering more productive relationships and effecting local food policy change.

\section{Planning and evaluation}

- Generate a robust strategic plan and planning process. Create a schedule for revisiting and revising the mission, goals, role, function, and governance structure of the council.

- Conduct biannual process evaluations and annual impact evaluations.

\section{Capacity-building}

- Develop shared definitions of what constitutes "projects," "programs," and "policies," and maintain a clear understanding of what type of work is appropriate for the council to engage in. With each phase of strategic planning, revisit this understanding to make sure that each proposed work plan or activity is within the scope of the council's role.

- Provide regular policy literacy and capacitybuilding trainings and agree upon who is responsible for their design and implementation.

- Establish and maintain realistic expectations for council members regarding their level of autonomy and authority in the decisionmaking process.

\section{Communication}

- Foster open two-way communication between council members and government staff and ensure that both parties have a shared understanding of their respective roles and responsibilities.

- Provide regular opportunities for FPCs to present recommendations directly to elected officials and for elected officials to provide feedback on those recommendations. This will help to ensure that the work 
of the council remains relevant to decisionmakers and that staff liaisons are not controlling the information flow between the council and elected officials.

\section{Membership and representation}

- Negotiate a transparent membership recruitment and selection process.

- Clearly define "expertise" and develop a common understanding of the variety of perspectives necessary to create a representative council membership.

- Maintain connection with the communities the council represents, and seek input from the public regularly. Ensure that community engagement meetings are as accessible as possible to achieve a broad range of input from a diverse constituency.

As this list of recommendations reveals, many of the challenges experienced by former PMFPC members and government staff liaisons are not unique to food policy, but speak to the broader arena of public participation in the policy process. Our research suggests that in order to effectively influence local policy change, targeted efforts must be made to resolve the dissonance between local government agendas and practices of citizen engagement. Most importantly, it is critical to negotiate, agree upon, and clearly articulate the roles and responsibilities of council members, government staff liaisons, and elected officials in contributing to a productive public process that empowers citizens, serves government officials, and holds all parties accountable. Although conflict is certain to arise when invested stakeholders come to the table to effect policy change, a sustained effort must be made to foster trust between citizens and local government; to evaluate the usefulness of established roles, structures, and processes; and to make the changes necessary to maintain the relevance of an organization throughout its life.

\section{Acknowledgements}

We extend our sincere gratitude to former members of the Portland Multnomah Food Policy
Council and to city of Portland and Multnomah County staff for the time and energy they dedicated (and continue to dedicate) to advancing food policy in the region. We are especially indebted to those who shared their experiences with us in the hope that others might benefit. We thank Nathan McClintock and Andy Fisher for their constructive feedback on multiple drafts of this paper. We also thank Betty Izumi, Suzanne Briggs, and Anita Yap for their guidance and comments throughout various stages of this research project. Finally, we thank the journal reviewers and editors for their comments and suggestions for improving this paper.

\section{References}

Arnstein, S. R. (1969). A ladder of citizen participation. Journal of the American Institute of Planners, 35(4), 216-224. http://dx.doi.org/10.1080/01944366908977225

Asimov, E. (2007, September 26). In Portland, a golden age of dining and drinking. The New York Times. http://www.nytimes.com/2007/09/26/dining/ 26port.html?pagewanted $=$ all $\& \quad r=0$

Beckie, M. A., Hanson, L. L., \& Schrader, D. (2013). Farms or freeways? Citizen engagement and municipal governance in Edmonton's food and agriculture strategy development. Journal of Agriculture, Food Systems, and Community Development, 4(1), 15-31. http://dx.doi.org/10.5304/jafscd.2013.041.004

Borron, S. M. (2003). Food policy councils: Practice and possibility. Eugene, Oregon: Congressional Hunger Center. Retrieved from http://hungercenter. wpengine.netdna-cdn.com/wp-content/uploads/ 2011/07/Food-Policy-Councils-Borron.pdf

Burawoy, M. (1998). The extended case method. Sociological Theory, 16(1), 4-33. http://dx.doi.org/10.1111/0735-2751.00040

Burgan, M., \& Winne, M. (2012). Doing food policy councils right: A guide to development and action. Mark Winne Associates. Retrieved from http://www.markwinne.com/wp-content/ uploads/2012/09/FPC-manual.pdf

Burros, M. (2006, January 4). In Oregon, thinking local. The New York Times. http://www.nytimes.com/ 2006/01/04/dining/04well.html 
Caraher, M., Carey, R., McConell, K., \& Lawrence, M. (2013). Food policy development in the Australian state of Victoria: A case study of the Food Alliance. International Planning Studies, 18(1), 78-95. http://dx.doi.org/10.1080/13563475.2013.750939

Center for a Livable Future. (2014). Food policy council directory. Retrieved November 11, 2014, from http://www.jhsph.edu/research/centers-andinstitutes/johns-hopkins-center-for-a-livablefuture/projects/FPN/directory/index.html

City of Portland. (2002). City of Portland resolution no. 36074. Retrieved from https://www.portland oregon.gov/bps/article/481225

City of Portland \& Multnomah County. (2012). Portland Multnomah Food Policy Council operating guidelines, January 2012. Electronic copy in possession of authors.

Cohen, N., \& Reynolds, K. (2014). Urban agriculture policy making in New York's "new political spaces": Strategizing for a participatory and representative system. Journal of Planning Education and Research, 34(2), 221-234. http://dx.doi.org/10.1177/0739456X14526453

Dahlberg, K. A. (1994, June). Food policy councils: The experience of five cities and one county. Paper presented at the Joint Meeting of the Agriculture, Food, and Human Values Society and the Society for the Study of Food and Society, Tucson, Arizona.

Dahlberg, K. A., Clancy, K., Wilson, R. L., \& Donnell, J. O. (1997). Strategies, policy approaches, and resources for local food system planning and organizing. Retrieved from http://unix.cc.wmich.edu/ dahlberg/F1.pdf

DiLisio, C. (2011). Food policy councils: Helping local, regional, and state governments address food system challenges [Food System Planning Briefing Paper]. Chicago: American Planning Association. Retrieved from http://ucanr.edu/sites/MarinFoodPolicyCouncil/ files/178441.pdf

Duran, B., Wallerstein, N., Avila, M. M., Belone, L., Minkler, M., \& Foley, K. (2012). Developing and maintaining partnerships with communities. In B. A. Israel, E. Eng, A. J. Schulz, \& E. A. Parker (Eds.), Methods for community based participatory research for health (2 $2^{\text {nd }}$ Ed.) (pp. 43-68). San Francisco: Jossey-Bass.

Fitzgerald, N., \& Morgan, K. (2014). A food policy council guide for Extension professionals. Journal of Extension, 52(2). Retrieved from http://www.joe.org/joe/2014april/a6.php
Fox, C. (2010). Food policy councils: Innovations in democratic governance for a sustainable and equitable food system. Los Angeles: Los Angeles Food Policy Task Force. Retrieved from http://goodfoodlosangeles.files. wordpress.com/2011/01/fpc final dist-5-indd.pdf

Griffin-Valade, L., Kahn, D., \& Gavette, K. (2013). Urban services policy and Resolution A: Core city services not articulated; 30-year-old commitments obsolete.

Portland, Oregon: Office of the City Auditor.

Retrieved from http://www.portlandonline.com/ auditor $/$ index.cfm?c $=60923 \mathrm{\& a}=441094$

Harper, A., Shattuck, A., Holt-Giménez, E., Alkon, A., \& Lambrick, F. (2009). Food policy councils: Lessons learned. Oakland, California: Institute for Food and Development Policy. Retrieved from http:// foodfirst.org/publication/food-policycouncils-lessons-learned/

Hatfield, M. M. (2012). City food policy and programs: Lessons harvested from an emerging field. Portland, Oregon: City of Portland, Oregon Bureau of Planning and Sustainability. Retrieved from https://www.portlandoregon.gov/bps/article/ $\underline{416389}$

Irvin, R. A., \& Stansbury, J. (2004). Citizen participation in decision making: Is it worth the effort? Public Administration Review, 64(1), 55-65. http://dx.doi.org/10.1111/j.1540-6210.2004. 00346.x

Mah, C. L., Baker, L., Cook, B., \& Emanuel, B. (2013). The Toronto Food Policy Council and the Toronto Food Strategy: Focusing on food systems and health at the city-region level. SCN News, 40, 69-71. Retrieved from http://www.unscn.org/files/ Publications/SCN News/SCNNEWS40 final standard res.pdf\#page $=69$

McClintock, N., Wooten, H., \& Brown, A. (H.). (2012). Toward a food policy "first step" in Oakland, California: A food policy council's efforts to promote urban agriculture zoning. Journal of Agriculture, Food Systems, and Community Development, 2(4), 15-42.

http://dx.doi.org/10.5304/jafscd.2012.024.009

Multnomah County. (2002). Resolution No. 02-093: Establishing a Portland/Multnomah County Food Policy Council, a subcommittee of the Portland/Multonomah County Sustainable Development Commission. Retrieved from https://multco.us/file/02-093pdf 
Multnomah County. (2013). Resolution No. 2013-041: Formation of the Multnomah County Food Advisory Board and Appointment of Members. Retrieved from https://multco.us/file/2013041pdf

Norris, M., \& Block, M. (2009, October 23). Portland, Ore., grocer sells in an "alternate universe" [Radio broadcast]. National Public Radio. Retrieved from http://www.wbur.org/npr/114099735

Packer, M. M. (2014). Civil subversion: Making "quiet revolution" with the Rhode Island Food Policy Council. Journal of Critical Thought and Praxis, 3(1), 1-26. Retrieved from http://lib.dr.iastate.edu/jctp/vol3/iss1/6/

Portland Area Food Forum [PAFF]. (n.d.). What is PAFF? Retrieved Jan. 3, 2015, from http://pdxfoodforum.org/what-is-paff/

Portland Multnomah Food Policy Council [PMFPC]. (2006). Portland Multnomah Food Policy Council chair and vice-chair scope of work. Electronic copy in possession of authors.

PMFPC. (2012a). Meeting minutes, July 11. Electronic copy in possession of authors.

PMFPC. (2012b). Meeting minutes, August 8. Electronic copy in possession of authors.

PMFPC. (2012c). Meeting minutes, September 12. Electronic copy in possession of authors.

Robbins, J. (2005, July 31). Think global, eat local. Los Angeles Times. http://articles.latimes.com/2005/ jul/31/magazine/tm-localfood31

Sanoff, H. (2000). Community participation methods in design and planning. New York: Wiley.

Santo, R., Yong, R., \& Palmer, A. (2014). Collaboration meets opportunity: The Baltimore Food Policy Initiative. Journal of Agriculture, Food Systems, and Community Development, 4(3), 193-208. http://dx.doi.org/10.5304/jafscd.2014.043.012
Scherb, A., Palmer, A., Frattaroli, S., \& Pollack, K. (2012). Exploring food system policy: A survey of food policy councils in the United States. Journal of Agriculture, Food Systems, and Community Development, 2(4), 3-14. http://dx.doi.org/10.5304/jafscd.2012.024.007

Schiff, R. (2008). The role of food policy councils in developing sustainable food systems. Journal of Hunger and Environmental Nutrition, 3(2-3), 206-228. http://dx.doi.org/10.1080/19320240802244017

Scott, B., Scott, R., Oppenheimer, S., Walton, D., \& Gahn, J. (2011). Food policy councils: Getting started. Tahlequah, Oklahoma: Cherokee Nation, Healthy Nation Division. Retrieved from http://okfarmand food.org/wp-content/themes/OKFarmandFood/ documents/tools/Getting Started-Food Policy Council Toolkit.pdf

Timberg, S. (2008, December 14). The novel that predicted Portland. The New York Times. http://www.nytimes.com/2008/12/14/fashion/14 ecotopia.html

Wang, X. (2001). Assessing public participation in U.S. cities. Public Performance and Management Review, 24(4), 322-336. http://dx.doi.org/10.2307/3381222

Yang, K., \& Callahan, K. (2005). Assessing citizen involvement efforts by local governments. Public Performance and Management Review, 29(2), 191-216. Retrieved from http://mesharpe.metapress.com/ index/dwvcwal75pg676rx.pdf

Yeatman, H. (1994). Food policy councils in North America - Observations and insights [Final Report on a World Health Organization's Travelling Fellowship]. Wollongong, Australia: Author. Retrieved from https://www.uow.edu. au/content/groups/public/@web/@,health/ documents/doc/uow025389.pdf 